\title{
Electricity Access for Remote Sub-villages Around Bali: Local Resources and Technology Assessments
}

\author{
Nyoman S Kumara, WG Ariastina, IAD Giriantari, and W Sukerayasa \\ Teknik Elektro Universitas Udayana, Bali \\ Contact Person: \\ Nyoman S Kumara \\ Jurusan Elektro Fakultas Teknik Universitas Udayana \\ Kampus Bukit Jimbaran, Kuta Selatan, Bali \\ Telp: 0361-703315, Fax: 0361-703315, E-mail: satya.kumara@ee.unud.ac.id
}

\begin{abstract}
Abstrak
Bali merupakan salah satu tujuan wisata Indonesia baik bagi wisatawan domestik maupun internasional. Hal ini berdampak positif dan telah mampu merubah pulau Bali menjadi salah satu provinsi yang memiliki pendapatan domestik regional bruto yang cukup tinggi dan tingkat kehidupan yang cukup baik bagi sebagian besar penduduknya. Walaupun demikian, ternyata masih ada sebagian dari wilayah di Bali yang belum memiliki akses energi listrik, sementara telah diakui secara luas bahwa energi listrik memiliki peran penting dalam upaya mencapai berbagai sasaran yang termasuk dalam tujuan pembangunan milenium
\end{abstract}

Tulisan ini merupakan hasil pendahuluan dari penelitian untuk meninjau status dari wilayah dan/atau penduduk di Bali yang belum terjangkau oleh jaringan distribusi listrik, termasuk tinjauan terhadap potensi sumber daya lokal baik alam dan masyarakat, dalam upaya menggali solusi penyediaan energi listrik yang bersih dan berkelanjutan.

Kata kunci : listrik pedesaan di Bali, dusun tanpa listrik, energi listrik terbarukan

\begin{abstract}
Bali is one of main tourist destination in Indonesia both for domestic and international holiday makers. This has transformed the island into one of the provincial region that has high gross regional domestic product and good living standards for most of its population. However, it appears that some areas in Bali still without access to electricity while it is widely acknowledged that electricity provides an essential role in achieving many of the millennium development goals.

This paper presents an intermediate finding on a research in reviewing current status of the unelectrified sub-villages around Bali, including assessment on its local resources such as natural, social and human resources, to identify solutions in developing appropriate systems using available generation technologies to provide green and sustainable electrical energy for basic uses in the subvillages around Bali.
\end{abstract}

Keywords: Bali rural electrification, unelectrified sub-villages, renewable electricity generation

\section{INTRODUCTION}


Bali is the center of Indonesia's tourists industry and has become one of top world holiday destination. It has received various international awards and recently nominated as the world best island tourist destination. The development of Bali has been and will likely to continue to be focused or at least closely linked to tourisms industry which will benefit the economy and hence people. All of this has given the island advantages over other eastern parts of Indonesia such as high direct tourism tied investments and also extensive infrastructures development. For example, good road access, telecommunication network in the form of landlines or wireless services is accessible virtually in every part of the island, well distributed elementary to senior high public schools, local health clinics and hospitals, as well as other facilities. This development has enabled most people who live in Bali to enjoy relatively good standard of living.
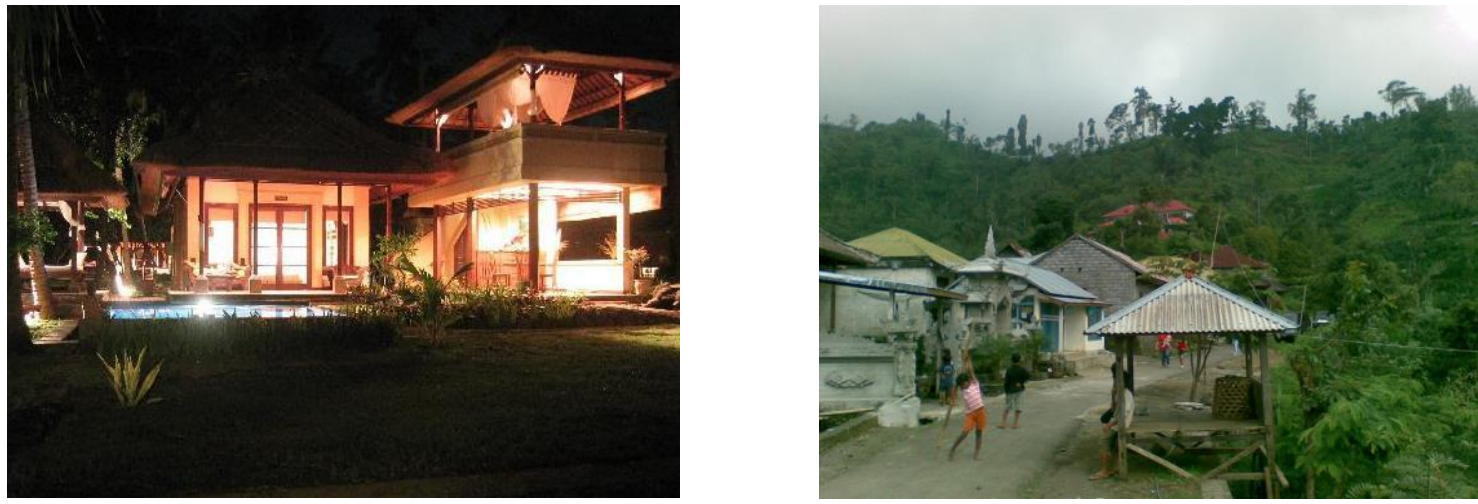

Figure 1 Villa at night in Bali [22] and one of the unelectrified village in Kintamani

Despite its intense development, it appears some areas in Bali are still fall to desa tertinggal or undeveloped village category. This category is given to villages if they do not yet have various basic infrastructure indicators such as schools, external road access, health facilities, clean water, fuel source, electricity, and other indicators. Therefore, the important of providing these basic infrastructures for people in the villages are two folds. First is as part of the national development to eradicate poverty and second is to implement the constitutional mandate as stipulated in our UUD 45 in which it says that earth and its resources should be utilized to benefit its people irrespective of their geographical positions. Among these indicators, access to electricity has a vital and strategic role in supporting the whole development particularly education, health, and economy. But due to various constraints some people are still without it.

PT PLN (Persero) is the state electricity company that has been given the responsibility to manage the national electricity sector. Its role is, together with private sectors to generate, and currently transmit, distribute, and sell the electricity to people and industry throughout the country. While it follows business principles as a company, PLN also has to observe its public service obligation by providing energy access to the less economically viable areas. In Bali, the electricity is managed by PLN Distribusi Bali, a branch of PLN. Over the years, the company has been successfully achieved full villages electrification in Bali [1]. However, many of sub-villages are not yet covered. A sub-village is the smallest organization unit in the governmental administration. A village usually comprises of one or more sub-villages. These sub-villages are scattered all around Bali and normally located far from the center of the village and mostly in the remote areas such as high in the mountain, on the deep of the valleys, and also in Nusa Penida, a small island in the south of Bali. It is perhaps due to this geographical challenge; the utility company has not been able to extend its distribution networks to reach out for this part of the population.

Most of the unelectrified sub-villages of Bali is scattered around Kintamani, South East of Singaraja, and Karangasem all of which are neighboring to each other except Nusa Penida which is located in the south eastern of Bali island separated by a small strait, the Badung straits. The sub-villages in Kintamani and South East of Singaraja areas are characterized by common geographic such as high altitude, green areas with forests, various dry land farming such as lime, local orange fruits, gloves, 
coffee, corns, sweets potatoes, and also cattle such as cows and lambs. Therefore, land in these areas is fertile and productive farm land. Consequently, picture of the economy is good as shown by good housing, ownerships of transport vehicles such as motor cycle, van, and even lorries or trucks. Access to external villages or to outside markets via road are relatively good although some parts are local or need repair and maintenance. Education is also good as indicated by good schools' building, healthy and happy children. Meanwhile, the unelectrified areas in Nusa Penida and Karangasem are quite different from the two previous areas. Although they are located far from each other, their geographic characteristics are rather similar. The lands are mostly dry, sit on high altitude with scattered plantation, and lack of clean water source. Karangasem is in the area of Agung mountain, the highest peak in Bali. In this two areas wind speed is better than any other area in Bali.

Currently, our electricity is mainly generated using fossil-based primary source such as oil, gas, and coal [2]. In a conventional approach, a huge power generation station is developed to produce large amount of electricity and then transmitted through long distance to reach for the densely-populated areas in the center of economy and or administration. On this approach, it involves large amount of investments and will require lengthy construction and administration processes. It is perhaps due to these reasons that Indonesia is now experiencing unbalanced supply and demand which led to electricity crisis [2]. Also, one important factor is that the conventional-based power generation poses high impacts on to the environment such as the phenomenon of global warming and moreover our natural reserves are in a diminishing state. Therefore, cleaner and more sustainable electrical energy generation should be within the framework of the solution in providing electricity access for these remote areas.

This paper presents early findings on the status of unelectrified areas around Bali. The research involves identifying sub-villages in Bali that do not have access to electricity and to assess their local resources including human and social resources to support development plan to provide electricity access. The renewable technology generation will be an important consideration in reviewing the potential solutions for the target areas taking into account the geographic characteristics and the future development plan of the utility company. The works undertaken in this research is supported by the National Strategic Research award. The paper starts with general introduction of Bali and its development relevant to the electricity and followed by brief discussion on the geographic of the unelectrified areas around Bali. The paper will identify resources in the target area in drawing development plan for their electricity supply. Discussion will also include the appropriate renewable technology generation suitable for each of the target area. As this is an on going research the results presented here reflects the progress achieved so far. The publication of this early works hopefully will provide some information to any parties who are interested in developing or implementing any rural electrification program in Bali.

\section{ELECTRIFICATION OF RURAL AREA}

Rural area is a huge part of Indonesia with 68.134 total number of villages spread across 13.600 islands. Since the year 2006, almost $80 \%$ of the villages have had access to electricity. Rural electrification in Java has achieved nearly $98 \%$ but the rest of the country is only approaching $60 \%$ [3]. Although rural electrification program has achieved significant part of its targets but still leaves some of the villages, between 6.000 to 6.244 villages, without electricity yet [4]. This figure does not take into account the sub-villages. Various programs have been devised and partly implemented for the electrification of this rural area. For example, the provision of central and regional budgets for rural electrification and the establishment of local institution to support the operation and maintenance of any demonstration program. And eventually as stated in the National Energy Blueprint, the government has set to achieve national electrification ratio of $95 \%$ by the year 2025 [5].

In Bali, the total number of villages is 706 spread in the 56 sub-districts administration. PLN has been able to achieve full villages electrification, or village electrification ratio of 100\%, in 1995 [6]. However, it is clear that the electrification only reaches the villages but not all of the sub-villages. A 
village is the lowest administration unit of the government and led by a chief village. The administrative area of a village can cover huge geographic areas and therefore is subdivided into subareas. Each of this sub-area is designated as sub-village. A sub-village is led by sub-village chief who is elected by the people. A village typically consists of between three to four sub-villages. Generally, the name of the village is adopted from the name of the most densely populated sub-village which normally more accessible. Based on data available from the state utility company, regional government, and various sources there are approximately 45 sub-villages that has not been electrified as of the end of year 2008. Table 1 shows the list.

Table 1 The unelectrified sub-villages in Bali at the end of 2008

\begin{tabular}{|c|c|c|c|c|}
\hline Districts & Sub-districts & Villages & Sub-villages & Remarks \\
\hline \multirow[t]{15}{*}{ Bangli } & Kintamani & Batur Selatan & Tandang Buana Sari & \\
\hline & & Kintamani & Gunung Kunyit & \\
\hline & & Manikliu & Saap & \\
\hline & & Satra & Tanah Gambir & \\
\hline & & Sukawana & Giringan & \\
\hline & & & Kubusalya & \\
\hline & & & Kuит & \\
\hline & & Songan B & Kayu Selem & \\
\hline & & & Peradi & \\
\hline & & & Kendal & \\
\hline & & & Kayu Padi & \\
\hline & & Selulung & Masahan & \\
\hline & & & Tiangan & \\
\hline & & Terunyan & Madia & \\
\hline & & & Bunut & \\
\hline \multirow[t]{4}{*}{ Buleleng } & Kubutambahan & Pakisan & Mengandang & \\
\hline & & & Kelandis & \\
\hline & & Bontihing & Rendetin & \\
\hline & Banjar & Kaliasem & Punggang & \\
\hline \multirow[t]{13}{*}{ Karangasem } & Rendang & Besakih & Temukus & \\
\hline & & & Kesimpar & \\
\hline & Kubu & Ban & Cegi & \\
\hline & & & Balong & \\
\hline & & & Manik Aji & \\
\hline & & & Daya & \\
\hline & & & Pengalusan & \\
\hline & & & Darmaji & \\
\hline & & & Pucang & \\
\hline & & & Bunga & \\
\hline & & Tianyar Tengah & Pedahan Kaja & \\
\hline & & Seraya Tengah & Kacang Balung & \\
\hline & & & Belubuh & \\
\hline \multirow[t]{13}{*}{ Klungkung } & Nusa Penida & Kutampi & Jurangaya & \\
\hline & & & Pulagan & \\
\hline & & Tanglad & Wates & \\
\hline & & Sekartaji & Sedihing & \\
\hline & & Batu Kandik & Dungkap I & \\
\hline & & & Dungkap II & \\
\hline & & & Bangun Urip & \\
\hline & & & Antapan & \\
\hline & & & Sukun & \\
\hline & & & Bingin & \\
\hline & & Sakti & Semaga/Penaga & \\
\hline & & Ped & Pendem & \\
\hline & & & Seming & \\
\hline
\end{tabular}

However, as this research progresses, it appears there are more areas still without electricity but has not been included in the utility list. At the beginning of this research, letters were sent to various subdistrict offices around Bali to obtain more information regarding the unelectrified sub-villages in their 
administrative area. And we are beginning to receive responses. For example, the village chief of Pangkung Paruk has informed that there are approximately 693 households within his village area does not have access to electricity yet. From the sub-district office of Kubutambahan we have been informed that 19 sub-villages are not connected to the utility's distribution networks. We suspect there will be more similar reply as we are expecting more responses from other sub-districts offices around Bali.

\section{POTENTIAL OF LOCAL RESOURCES}

The availability of local natural resources such as waterfall or water streams, wind, accessible solar radiation, biomass, or any other natural potentials is the key factor in considering the development electricity generation systems. Further, the capacity of proposed system will be determined by the effective capacity of the selected resource and the availability of the generation technology. Other important factors which also essential is human resources available in the village. For example, the local manpower is required for the operation, maintenance, or payment collection from the villagers after the system is built and commissioned by the installer for a short period of time. Also, the presence of social or village community organizations can be utilized as an integral part of the overall supply system to ensure safe, secure, and sustainable service of the plant.

Nationwide, the potential of micro hydro is estimated at around $500 \mathrm{MW}$. In 2006, the installed capacity of microhydro plant is around $84 \mathrm{MW}$ [6]. Bali has two large size lakes that act as water reservoirs together with rivers and streams. Waterfall is also available in various places and with an estimated 162 total number of rivers and 1.274 springs spread in eight districts around the island. JICA has estimated the total surface water flow or rivers is around 4.965 million cubic meter [8]. And with respect to rainfall, most of Bali has an average annual rainfall of $2.000 \mathrm{~mm}$ [9]. These geographical facts and figures suggest that Bali has enough water resources and if further combined with the high altitude will constitute a promising potential for hydro electricity particularly in the micro hydro scale.

Geographically Indonesia lies in the equator region. This location lend itself with the abundance of sunlight as it is available most of the time all year round. It is estimated that daily potential of solar electricity is around $4.8 \mathrm{kWh} / \mathrm{m}^{2}$ [3]. In 2007, the total installed capacity of solar electricity in Indonesia is estimated at around $12 \mathrm{MW}$ [10]. In Nusa Penida Bali, PLN has already developed centralized solar electricity system with capacity of $30 \mathrm{~kW}$. Ministry of Energy and Mining Resources (DESDM) office has also installed small solar home systems in a number of sub-villages in Bali.

Generally, wind that flows in the country has speed range of $3-6 \mathrm{~m} / \mathrm{s}$. The actual wind speed for particular location will require specific wind survey and measurement. In 2007, nationwide installed wind electricity is estimated at $1 \mathrm{MW}$ [10]. In Bali, wind speed is generally toward the bottom estimate except in two of areas in Karangasem and Nusa Penida where wind speed is more promising. In Nusa Penida, PLN has already developed small wind farm with eight wind turbine towers capable of producing 735 kilowatt electricity.

In rural renewable electricity development, the role of local people is important for a number of reasons. Firstly, the installer or provider of the system is normally inaccessible from the village therefore training local people to be able to carry simple and routine tasks will solve the problem. Secondly, the presence of local resident technicians will deter any possible vandalisms. And if the plant is centralized in which power is sold to the villagers, local collector will ensure correct and on time payment installments. The presence of local organizations such as youth organization known as STT, traditional farming organization or known as Subak, cooperatives, or any other organizational forms are beneficial in supporting the development of the program.

The potential use of electricity for people when it becomes available is relatively clear. Although, due to geographical condition of the sub-villages hence the needs and the use of electricity varies as well. But in general, lighting is the main purpose. Some villagers have had radio, television and even mobile 
phone. In Kubusalya, school has been given sets of personal computers as part of government educational program but lack of electricity has hampered schools' teachers and children from using it.

\section{RENEWABLE GENERATION FOR RURAL ELECTRICITY}

Renewable generation technology has characteristics that is inherently ideal for providing electrical energy in remote areas. It uses local primary energy source, power is generated locally, and also utilized locally. This means minimum distribution networks and probably unnecessary investments in the case of stand alone configuration. However, one major constraint for the penetration of renewable generation systems, particularly in remote areas, is the high initial cost required. However, as the important of electricity access is clearly understood, many governments and international organizations have developed various programs to assist those affected by the lack of energy access. Various rural electrification using renewable systems projects have been implemented in Indonesia. The projects are funded through assistance of international organization such as World Bank (WB), United Nations Development Projects (UNDP), United Nations Industrial Development Organizations (UNIDO), European Union (EU), German Technical Corporation (GTZ), Global Environment Facility (GEF), Japan for International Corporation Agency (JICA), or other institutions and organizations.

According to the National Energy Blueprint, the government has set target to achieve just over 3\% renewable electricity generation by 2025 [3]. This percentage while seems little in number but it equates to hundreds of megawatts power capacity. It is most likely that this capacity will be significantly met through rural electrification using renewable technology. The government has developed a number of renewable demonstration projects throughout the country. It has also provided mechanisms by issuing appropriate legislations for renewable electrical energy developers, cooperatives or business entity, to sell its power to the utility. Small scale decentralized system is suitable for houses in rural areas as they are dispersed over large hills or valleys. In the case of Bali, the renewable systems that are more likely to be developed is microhydro plant, solar power system, or wind turbine. Obviously, the nominated technology will be site specific depending on the local resource. In term of technological development, these technologies have reached relatively mature status and various small scale products have been released by manufacturers both by domestic manufacturer or international vendor.

Microhydro plant which has generating capacity between 5 to $200 \mathrm{kWatt}$ has been developed at various places in the country to provide electricity for rural areas. In the case of Bali, water resource and microhydro is also one of the solution to provide green and sustainable power. With the advanced of microhydro technology, particularly the availability of domestically manufactured components, small streams and low head can be harnessed to provide basic electricity needs for people in the villages. A very small system with nominal capacity as low as 100-5000 W, known as picohydro [11], is also available, enough to power a typical town house which has $450 \mathrm{VA}$ ceiling power. In Bali, PLN has developed a $30 \mathrm{~kW}$ microhydro in Karangasem that currently managed by local cooperative.

Historically, Indonesia is among one of a few developing countries in the world to experience the benefit of solar electricity on its early development. Since 1980s solar electricity has reached condition in which its commercial value is suitable for small scale home application, or commonly known as solar home system (SHS). Village of Sukatani and Wawatobe are among the first solar electricity installation in the country dated back to the 1980s. In the domestic current market, solar electricity manufacturers have marketed wide range of solar home systems that has single panel output ranging from $5 \mathrm{Wp}$ up to $75 \mathrm{Wp}$ [12], [13].

Technologically, wind turbine generator is now available for wide range of nominal power output. It starts from $1.3 \mathrm{~kW}$ small system [14] to huge tower of megawatts power output capacity such as Enercon-126 [15]. A range of micro turbines with low voltage and power such as $600 \mathrm{~W}$ output is also available [16]. The availability of wide range power output will enable a small scale installation as it becomes more affordable in the context of rural application. 


\section{SUMMARY}

Although Bali has received great attention with respect to infrastructure developments to support the tourist based-economy, it still has some of its area and people without access to the electricity. This paper has presented an intermediate result regarding the unelectrified areas in Bali. Further, the paper has briefly discussed the geographical characteristics of these areas together with discussion on viable technologies that could be implemented in those areas to provide accessible, reliable, green, and sustainable electricity.

\section{REFERENCES}

[1] BPMD Bali, "Perkembangan Desa/Dusun Berlistrik Propinsi Bali s/d Desember 2008", BPMD Propinsi Bali, 2006

[2] Adnyana, N., "Tantangan Dalam Mengelola Kelistrikan Nasional", Kuliah Umum Program Pascasarjana Manajemen Energi Teknik Elektro Unud, PT PLN (Persero) Distribusi Jawa Bali, 2008

[3] Ariati, R., "Renewable Energy in Indonesia", Regional Training Workshop on Renewable Energy, Directorate New and Renewable Energy and Energy Conservation, Ministry of Energy and Mineral Resources, Bali, 2008

[4] Djamin, M., Lubis, A.Y., Dasuki, A.S., "Financial Scheme and Experience on Application of SHS in Indonesia", The Agency for Assesment and Application of Technology Indonesia, 2006

[5] DESDM, "Kebijakan Energi Nasional 2003-2020 Kebijakan Energi Yang Terpadu Untuk Mendukung Pembangunan Nasional Berkelanjutan", Departemen Energi Dan Sumber Daya Mineral, Jakarta, 2004

[6] Hutapea, M., "Country Plans and Policies for Developing and Implementing Renewable Energy Programs in Indonesia", Directorate General of Electricity and Energy Utilization Ministry of Energy and Mineral Resources, February 2006

[7] Bappeda Bali, "Rencana Umum Ketenagalistrikan Daerah (RUKD) Propinsi Bali Tahun 2004", Badan Perencanaan Pembangunan Daerah Bali Pemerintah Provinsi Bali, 2004

[8] Sarad Bali, "Salah Kelola Bencana Menganga", Majalah Sarad Bali, Edisi No. 101 Tahun IX September 2008

[9] Bakosurtanal, "Curah Hujan Bali”, Peta interaktif on-line oleh Bakosurtanal, tersedia di http://atlasnasional.bakosurtanal.go.id, diakses Juni 2009

[10] Ariati, R., "Microhydro Development in Indonesia", Workshop on Hydropower Competence Network for Education and Training (HCN), Directorate for New Renewable Energy and Energy Conservation Ministry of Energy and Mineral Resources Indonesia, Bangkok, 2003

[11] Williams, A., Maher, P. "Mini-grid Design for Rural Electrification: Optimization and Applications", School of Electrical \& Electronics Engineering, University of Nottingham, United Kingdom

[12] Ampair, "Water and wind power catalog 2008", Ampair Catalog Issue 5, 2007

[13] Sundaya, "Products Systems", tersedia online di www.sundaya.com, diakses Juni 2009 
[14] Raum Energy, "1.3 kW Wind Turbin System Specification Sheet”, Raum Energy Inc, Canada

[15] Enercon, "Enercon E126: World's most powerful wind turbine installed near Emden", Windblatt Enercon Magazine, Issue 04 I 2007

[16] Azetsurya, "Modul Surya", tersedia online di www.azetsurya.com diakses Juni 2009

[17] Davidson, O.R., "The Role of Energy in Achieving and Sustaining MDGs Africa", GNESD Africa, 2005

[18] Elektro Unud - YLKI Bali, "Semiloka Potensi Krisis Listrik di Bali dan Alternatif Solusinya", Yayasan Lembaga Konsumen Indonesia (YLKI Bali), Teknik Elektro UNUD, dan Yayasan Kertaning Jagat Bali (KERJA Bali), Denpasar, 2005

[19] DESDM, "Kebijakan Pengembangan Energi Terbarukan Dan Konservasi Energi (Energi Hijau)", Departemen Energi Dan Sumber Daya Mineral, Jakarta, Desember 2003

[20] World Bank, "World Bank Solar Home Systems Project 1997 - 2002"

[21] Bappeda Bali, "Kebijakan dan Pengembangan Energi Listrik di Bali", Badan Perencanaan Pembangunan Daerah (Bappeda) Propinsi Bali, 2006

[22] Amerta Bali Villas, "Amerta Bali Villas at Pemuteran", tersedia di http://www.tripadvisor.com/ Amertha_Bali_Villas-Pemuteran_Bali, diakses Juni 2009 